\title{
Yeni Bir Finansal Araç Olarak Sukuk: Çeşitleri, Türkiye Uygulaması ve Vergilendirilmesi
}

\author{
Erdal YILMAZ*
}

\section{ÖZET}

Faizsiz finansal araçlar, portföy çeşitliliği sağlamak ve inançlarından dolayı geleneksel finansal pazarlardan uzak duran yatırımcıları cezbetmek için uygun araçlar olarak kabul edilmektedir. Bu faizsiz finansal araçlar arasında en yaygın olarak faizsiz bono olarak da adlandırılan sukuk kullanılmaktadır. Sukuk, Ortadoğu'da ortaya çıktıktan sonra özellikle Malezya'da hızla yayılmıştır. Bu çalışmada Türkiye'de henüz uygulanmaya başlanan sukuk incelenmiş, çeşitleri ve vergilendirilmesi ile ilgili açıklamalarda bulunulmuştur. Çalışmada literatür taraması yapılmış ve yürürlükteki mevzuat detaylı şekilde gözden geçirilmiştir.

Anahtar Kelimeler: Sukuk, Faizsiz. Finansal Araçlar, Kira Sertifikası.

JEL Sinıflandirmast: M40, M41, F65.

\section{Sukuk As A New Financial Instruments: Types, Application And Taxation Of Turkey} ABSTRACT

Non-interest bearing financial instruments to diversify their portfolios and their faith away from traditional financial market standing as a convenient means to lure investors will be accepted. This is the most common among non-interest bearing financial instruments referred to as Islamic bonds Sukuk are used. Sukuk in Malaysia, especially in the Middle East after the occurrence spread quickly. In this study, the sukuk yet been implemented in Turkey are examined, types and descriptions have been made regarding the taxation. Within the scope of this study, the relevant literature has been reviewed and the legislation in force has been examined.

Keywords: Sukuk, Non-Inseterst Financial Instrument, Lease Certificate.

Jel Classification: M40, M41, F65.

\footnotetext{
*Öğr.Gör.Dr. Erdal Yılmaz, Ondokuz Mayıs Üniversitesi, Vezirköprü Meslek Yüksekokulu, eyilmaz@omu.edu.tr
} 


\section{GíRiş̧}

Sanayi devriminden sonra üretim şeklinin değişmesi ve işletmelerin büyük ölçekli üretim faaliyetlerine girişmesi ile birlikte finansman her geçen gün daha önemli bir konu haline gelmiştir. İşletmeler, faaliyetlerini sürdürebilmek ve gittikçe artan rekabet ortamında ayakta kalabilmek için kendilerine en uygun fonları temin etmek ve bunları en uygun yatırım araçlarında değerlendirmek durumunda kalmışlardır. Fon arz ve talebinin karşıllaştığı finansal piyasalarda tasarruf sahiplerinin mümkün olduğu kadar yüksek oranda fonlarını arz etmesi bu piyasaların etkinliği ve verimliliği açısından son derece önemlidir.

Finansal piyasalarda tasarruf sahipleri için en önemli husus elde edecekleri faiz veya kazanç oranlarıdır. İslâm dinindeki faiz ile ilgili hükümlerden dolayı geleneksel bankacılık sisteminin dışında kalan birikimlerin ekonomiye kazandırılması için faizsiz sisteme dayalı farklı finansal enstrümanlar geliştirilmiştir. Kâr ve zarara katılma esasına göre çalışan ve risk paylaşımını öngören sistem, dünyada daha çok faizsiz bankacılık (interest-free banking) ya da İslami bankacılık (islamic banking) olarak bilinmesine rağmen, Türkiye'de Katılım Bankacılığı (participation banking) olarak bilinmektedir (Parlakkaya ve Çürük, 2011:397). Katılım bankalarının ekonomiye farklı açılardan katkısı vardır. Finansal sisteme girmeyen fonların sisteme kazandırarak, tasarruf sahiplerine kazanç sağlaması, gelir dağılımını düzenleyici etkileri, reel sektöre kaynak aktararak ekonominin büyümesine olan katkıları söylenebilir. Bununla birlikte kayıt dışı ekonomik faaliyetlerin kayıt altına alınması, Kurumlar Vergisi, Katma Değer Vergisi, Kaynak Kullanımı Destekleme Fonu ve Banka ve Sigorta Muameleleri Vergisi ödeyerek kamu maliyesine katkıları, reel sektörün doğrudan fonlanması sebebi ile istihdamın sürekliliği ve artışı ile sosyo-kültürel faaliyetlere katkıları da sayılabilir (Ece, 2011:4).

Faizsiz finansal araçlar içerisinde en önemli gelişmeyi İslami tahvil veya faizsiz bono olarak da adlandırılan sukuk göstermiştir. 2012 yılı sonuna kadar dünya genelinde yaklaşık olarak 460 milyar dolarlık işlem hacmine ulaşan sukukun (IIFM, 2013) Türkiye'de uygulanması için yasal düzenlemeler yapılmaya başlanmış ve ilk sukuk ihraçları gerçekleştirilmiştir. Bu çalışmada genel olarak sukuk kavramı ve çeşitleri açıklandıktan sonra sukukun Türkiye uygulaması olan kira sertifikalarının işleyişi ve vergilendirilmesi ile ilgili bilgilere yer verilecektir.

\section{GENEL OLARAK SUKUK KAVRAMI, ÖZELLİKLERİ, GELIŞSIM SÜRECİ VE ÇEŞITLERI}

\subsection{Sukuk Kavramı}

Sukuk, "bir ayn (mal), menfaat, hizmet, belirli bir proje ve/veya yatırımın varlığı üzerinde eşit değerdeki hisseleri temsil eden mali vesikalar" şeklinde tanımlanmaktadır (Durmuş, 2010:143). İslami Finans Kurumları Muhasebe ve Denetim Organizasyonu (Accounting and Auditing Organization for Islamic Financial - AAOIFI) sukuku şu şekilde 
tarif etmiştir: "Sukuk, ihraç edildikten sonra eşit değerleri temsil eden; ihraçtan elde edilen tutarların önceden planlanan şekilde yatırım yapıldiğı; yapılan yatırım türüne göre duran varlıklar ve benzerleri üzerindeki haklar ve payların temsil edildiği ya da bir projede ya da özel bir yatırım faaliyetinde ortaklık hakkı veren sertifikalardır."

Geleneksel borçlanma araçları olan tahvillerin İslami prensiplere uyacak biçimde yeniden yapılandırılması sonucu sukuk ortaya çıkmıştır. Sukuk, İslam dinine göre haram olan faiz kazancı yerine yatırımcısına helal kazanç sunan menkul kıymetlerdir (Derigs ve Marzban, 2008:286). Tahvil, ödünç para bulmak için çıkarılan borç senetleridir. Buna karşılık sukukta, sukuk alıcısı ilgili varlıkta tam tasarruf hakkı kazanmaktadır. Sonuç olarak sukuk alıcısına sukuk varlıklarının satılmasından oluşacak hasılatın yanında sukuk varlıklarından elde edilen gelirlerden de pay alma hakkı verilmektedir. Sukuk ile tahvili birbirinden ayıran diğer bir özellik de tahvil ihraççının borcunu temsil ederken, sukuk ilgili varlıkta payı oranında malikliği temsil etmektedir. Öte yandan teknik olarak varlık senedi veya menkul kıymetleştirilmiş varlık şeklinde de isimlendirilebilecek olan (securitizied assets) sukuk, diğer senetlerden farklı olarak varlığa dayanmak zorundadır. (Tok, 2009:13). Sukuk sistemini anlamak için öncelikle Varlığa Dayalı Menkul Kıymet (VDMK) sistemini bilmek gerekmektedir. VDMK sisteminde alacak portföyüne sahip olan şirket, bu portföyü özel amaçlı şirkete (Special Purpose Vehicle/SPV) satmakta ve SPV ise portföyü menkul kıymete dönüştürmektedir. $\mathrm{Bu}$ arada yatırım bankaları da bu kıymetlerin yatırımcılara satılmasına aracılık etmektedirler. Sukuk sisteminde de, elle tutulur, gerçek ticari ilişkilerden doğan alacakların (örneğin kar-zarar ortaklığı) veya finansal kiralama sözleşmesinden doğan alacakların varlığa dayalı olarak menkul kıymetleştirilmesi söz konusu olduğundan, sukuk varlığa dayalı tahvil olarak da tavsif edilebilecektir (Tok, 2009:14). Sukuk ve tahvil arasındaki en belirleyici fark olarak; sukukun bir varlığa dayanan sertifika olması, tahvilin ise borç olarak alınan bir miktar paraya dayanan sertifika olmasıdır. Ayrıca tahvil de belli bir oranda gelir garantisi söz konusuyken sukukta böyle bir garanti yoktur. Ancak sukukta sahiplik hakkının yanında başka teminatlar sağlanabilmektedir.

Sukuk, bir varlık ya da proje üzerinde sahiplik hakkını sağlaması ve belli bir geliri garanti etmemesi yönünden hisse senetlerine benzemektedir. Ancak, hisse senedi, sahibine hissesi oranında şirkete ortaklık hakkını vermekte ve bu ortaklık belli bir süreyle sınırlandırılmamaktadır. Oysa sukuk, sahibine sadece sukuka konu edilmiş varlık üzerinde sahiplik hakkını tanımakta ve bu hak, anlaşmada önceden belirlenmiş olan tarihe kadar geçerli olmaktadır. Sukuk sertifikası sahipleri ayrıca, şirket yönetimine katılma, oy kullanma, rüçhan hakkı gibi hisse senetleri sahiplerinin sahip olduğu haklara sahip değildir. Sukukun geleneksel bono ve hisse senetleriyle karşılaştırıldığı tablo aşağıda gösterilmiştir. 
Tablo 1: Sukuk, Bono ve Hisse Senetlerinin Karşılaştırılması

\begin{tabular}{|c|c|c|c|}
\hline & Sukuk & Bono & Hisse Senedi \\
\hline İhraç Konusu & $\begin{array}{l}\text { Borç senedi değildir. } \\
\text { Belirlenmiş varlık ya da } \\
\text { proje üzerinde } \\
\text { bölünmemiş sahiplik } \\
\text { hakkı söz konusudur. }\end{array}$ & $\begin{array}{l}\text { İhraç edenin borcu söz } \\
\text { konusudur. }\end{array}$ & $\begin{array}{l}\text { Şirketin hissesinden } \\
\text { sahiplik hakkı söz } \\
\text { konusudur. }\end{array}$ \\
\hline $\begin{array}{l}\text { Varlığa Dayalı } \\
\text { Olma Durumu }\end{array}$ & $\begin{array}{l}\text { En az belirlenen oran } \\
\text { nispetinde maddi varlık } \\
\text { olmalıdır.(\%51-sukuku } \\
\text { icara için) }\end{array}$ & $\begin{array}{l}\text { Genellikle gerekli } \\
\text { değildir. }\end{array}$ & Gerekli değildir. \\
\hline Teminat & $\begin{array}{l}\text { Dayandığı varlıklar ya da } \\
\text { proje üzerindeki sahiplik } \\
\text { hakkı ile teminat } \\
\text { sağlamaya ek olarak } \\
\text { teminat artırımı ile de } \\
\text { teminat sağlar. }\end{array}$ & $\begin{array}{l}\text { İpotekli tahviller, } \\
\text { teminatlı borç senetleri } \\
\text { vb. dişında genellikle } \\
\text { teminat içermezler. }\end{array}$ & Teminat içermezler \\
\hline Anapara ve Gelir & $\begin{array}{l}\text { İhraççı tarafından garanti } \\
\text { edilmemiştir. }\end{array}$ & $\begin{array}{l}\text { İhraççı tarafından garanti } \\
\text { edilmiştir. }\end{array}$ & $\begin{array}{l}\text { Şirket tarafından garanti } \\
\text { edilmemiştir. }\end{array}$ \\
\hline Amaç & $\begin{array}{l}\text { Sadece İslam hukukuna } \\
\text { uygun amaçlar için ihraç } \\
\text { edilebilir. }\end{array}$ & $\begin{array}{l}\text { Her türlü amaç için ihraç } \\
\text { edilebilir. }\end{array}$ & $\begin{array}{l}\text { Her türlü amaca } \\
\text { uygundur. }\end{array}$ \\
\hline Senetlerin Satılması & $\begin{array}{l}\text { Belirlenmiş varlık ya da } \\
\text { proje üzerindeki sermaye } \\
\text { payının satışı söz } \\
\text { konusudur. }\end{array}$ & $\begin{array}{l}\text { Bir borç senedinin satışı } \\
\text { söz konusudur. }\end{array}$ & $\begin{array}{l}\text { Şirketin hisselerinin satışı } \\
\text { söz konusudur. }\end{array}$ \\
\hline $\begin{array}{l}\text { Senet Hamillerinin } \\
\text { Sorumlulukları }\end{array}$ & $\begin{array}{l}\text { İhraç edilen senetlere } \\
\text { katılım oranında dayalı } \\
\text { olduğu varlık/ teşebbüse } \\
\text { bağlı olarak tanımlanmış } \\
\text { bir sorumluluk söz } \\
\text { konusudur. }\end{array}$ & $\begin{array}{l}\text { Bono sahiplerinin } \\
\text { ihraççının mali durumunu } \\
\text { için herhangi bir } \\
\text { sorumluluğu yoktur. }\end{array}$ & $\begin{array}{l}\text { Sahip olunan şirket } \\
\text { hisseleri oranında şirketin } \\
\text { işlerinden sorumluluk söz } \\
\text { konusudur. }\end{array}$ \\
\hline
\end{tabular}

Kaynak: Nathif J. Adam and Abdulkader Thomas, Islamic Bonds, 1st Edition, London: Euromoney Books, 2004. Aktaran: Aslan, 2012:58

\subsection{Sukukun Gelişim Süreci}

Sukuk uygulamaları ilk kez Malezya Hükümeti tarafından 2001 yılında gerçekleştirilmiştir. Başlangıçta 500 milyon USD olarak ihraç edilen Malezya sukuklarının \% 51'i Körfez Ülkelerinde, \% 30'u Asya'da, \% 15'i Avrupa'da ve \% 4'ü de ABD'de satılmıştır. Uygulanan yapı ise bir kamu kurumu olan Federal Malezya Arsa Ofisi elindeki arsaların kurulan bir SPV'ye (Özel Amaçlı Şirket'e) satılarak, oradan Malezya Hazinesi'ne kiralanarak elde edilen kira gelirlerinin, SPV'ce ihraç edilen sukukların satıldığı kişilere gelir olarak aktarılmasını sağlayan bir yapı üzerine inşa edilmiştir (Güngören, 2011:98) 
Sukuk, 2003 yılından itibaren dünya çapında daha tanınır hale gelmiş ve 2007 yılında 34 milyar dolarlık ihraç rakamına ulaşmıştır. Bu konuda Malezya sukuk piyasasının ana pazarını oluşturduğu söylenebilir. 2009 yılında ise Endonezya ve Singapur'un da bu piyasaya hızlı bir şekilde girdikleri görülmektedir. Ancak "Kuveyt yatırım şirketlerinin sorunları, B.A.E.' deki emlak piyasası ve Suudi Arabistan'daki kredi darlı̆̆ı" nedenlerinden dolayı sukuk piyasası son yıllarda bu olumsuzluklardan etkilenmiştir (Türker, 2010:19).

Sukuk, ilk ihraçtan sonra ikincil piyasalarda işlem görebilmektedir. İkincil piyasa, menkul kıymetlerin likiditesini arttırarak birincil piyasaya talep yaratır ve gelişmesini sağlar. İkincil piyasada işlem gören ilk sukuk ise Bahreyn'de görülmüştür. Müteakiben Malezya, diğer İslam ülkeleri ve Müslüman olmayan ülkelerde de ihraçlar devam etmiştir. Uluslararası İslami Finans Piyasası (International Islamic Financial Market-IIFM) verilerine göre, sukuk ihraçlarında genellikle özel sektör tahvilleri büyük bir paya sahiptir. 2007 yılında ihraç edilen sukuk hacminin \% 81'i şirketler tarafından gerçekleştirilmiştir (Güngören, 2011:99).

Grafik 1: Dünya Çapında Toplam Sukuk İhraçları (milyon \$)

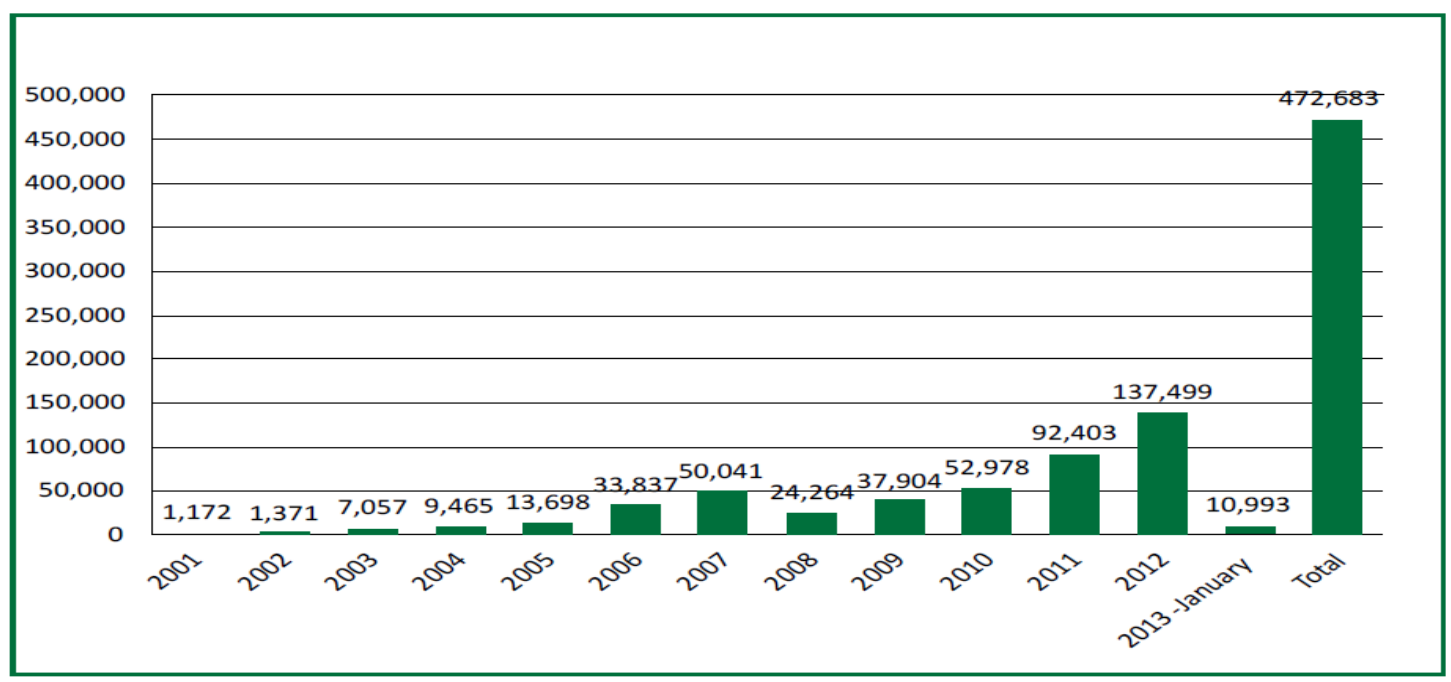

Kaynak: http://www.iifm.net/documents/iifm-sukuk-report, 10.10.2013

Grafik 1'de görüleceği üzere, 2001 yılında düşük bir işlem hacmi ile başlayan sukuk ihracı giderek yükselmiştir. Sukuk ihraçları, global ekonomik krizin yaşandığı 2008 yılı dışarıda bırakıldığında hemen her yıl bir önceki yıla göre önemli oranda artış göstermiştir. Örneğin; 2009'da \%40, 2011 yılında \%74, 2012 yılında \%49 oranında artış meydana gelmiştir. Aşağıdaki grafik, ülkeler bazında sukuk ihracını göstermektedir. 
Grafik 2: Sukuk İhraçlarının Ülkelere Göre Dağılımı

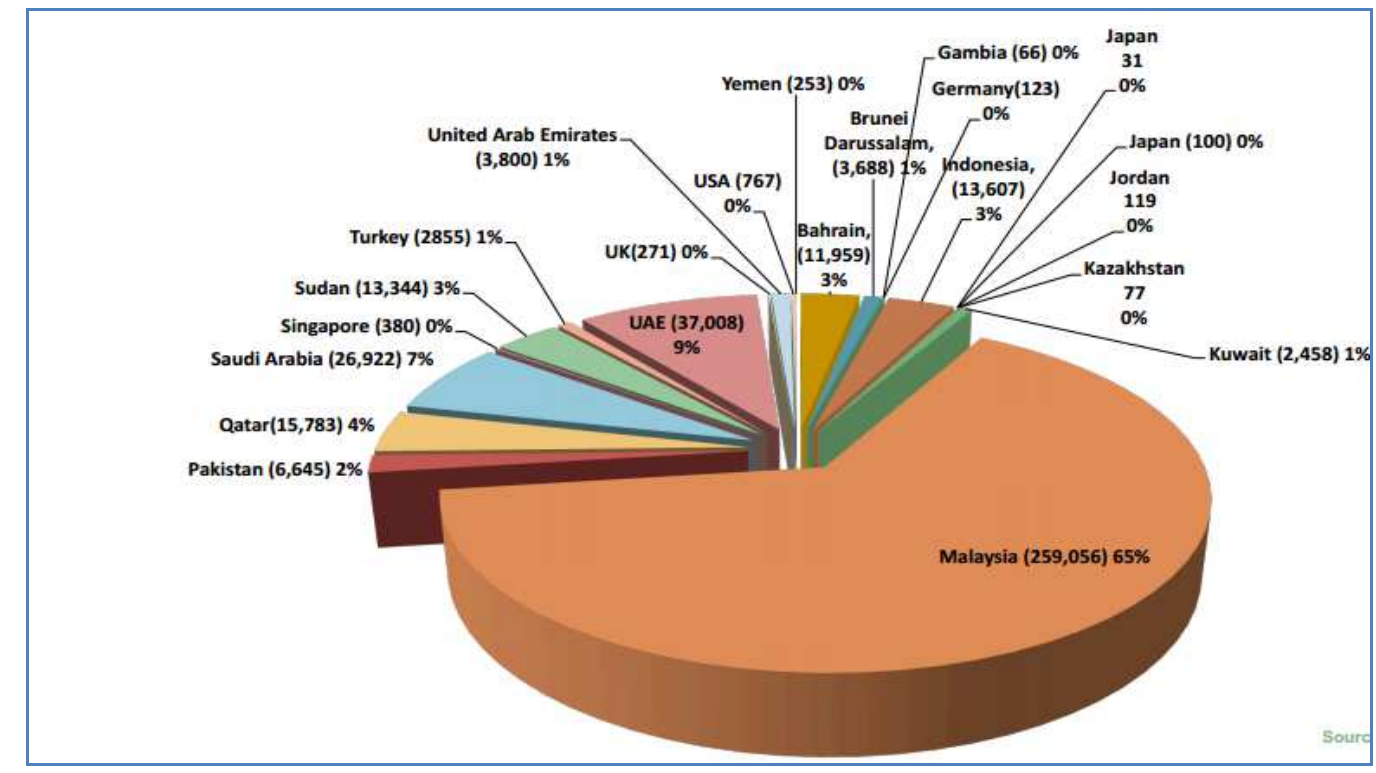

Kaynak: http://www.iifm.net/documents/iifm-sukuk-report, E.T. 10.10.2013

Grafik 2'de anlaşılacağı üzere dünya sukuk ihracının önemli bir bölümü Malezya tarafından gerçekleştirilmektedir. \%26,9 oranında Suudi Arabistan, \% 15 oranında Katar sukuk piyasasında Malezya'yı takip eden ülkelerdir. Türkiye sukuktaki ilk yılı ile birlikte pastadan \%1'lik bir pay almıştır.

Sadece İslam dünyasında değil, uluslararası piyasalarda da global bir yatırım aracı olarak kullanılmaya başlanan sukuk ihraçları, Lüksemburg Borsası'ndan sonra 20.7.2006 tarihinde ilk defa Londra Borsası'na da kote edilmiştir. Dow Jones Endeksi ve CitiGroup Mart 2006'da Dow Jones Citigroup Sukuk Indeks'ini hesaplamaya başlamış olup, İslam düzenlemeleri çerçevesinde ihraç edilen finansman sertifikası sukukların performansını ölçmek amacıyla kullanılmaktadır ( Küçükçolak, 2008:27).

Küresel sukuk piyasasında sağlanan gelişmeler İslam bankacılığındaki likidite imkanlarını artırırken bir taraftan da bu sağlanan gelişme sırasında ortaya çıkan sorunların çözümüne ilişkin uluslararası mekanizmalar geliştirilmektedir. Bu bağlamda, 2010 yılında TCMB'nin de kurucuları arasında bulunduğu "Uluslararası İslami Likidite Yönetim Şirketi" (International Islamic Liquidity Management Corporation- IILM) kurulmuştur. Söz konusu yapılanmanın amac1; İslami kurallara uygun gelirleri olan uluslararası bir varlık havuzu oluşturmak ve bu varlıklara dayanan yüksek dereceli, basit tasarımlı, uluslararası geçerliliği ve ikincil piyasası olan, katılımcı ülkelerdeki faizsiz bankacılık kuruluşlarının (İslam bankalarının) likidite gereksinimlerini karşılayacak hacim ve vadelerde düzenli olarak sukuk ihraç edilebilmesinin sağlanması olarak belirlenmiştir (Yakar vd, 2013:76). 


\subsection{Sukukun Başlıca Özellikleri}

Dikkat çekici bir hızla büyüyen İslamî finansal hizmetlerin doğal bir sonucu olarak ortaya çıkan sukuk, katılım bankaları başta olmak üzere finansal kurum ve kuruluşlara, işletmelere ve ülke hazinelerine finansal piyasalardan İslam hukukuyla uyumlu kaynak sağlama imkânı tanıyan bir araçtır (SARPEM, 2013:7).

Sukuk ihracının amacı, toplanan fonlar ile sahip olunan paya göre yeni bir projeye başlamak, mevcut bir projeyi geliştirmek veya toplanan fonları ticari bir faaliyetin finansmanı için kullanmaktır. Sukuk sisteminde yatırımcının veya sukuk sahibinin elde edeceği getiri; bir ticari faaliyetten, belirli bir varlığın mülkiyetinden ya da bir iş ortaklığından elde edilecek gelir üzerindeki hak sahipliğinden kaynaklanmaktadır (ERNST, 2013).

Sukuk, ihraç edildikten sonra eşit değerleri temsil eden; ihraçtan elde edilen tutarların önceden planlanan şekilde yatırım yapıldığı; yapılan yatırım türüne göre duran varlıklar ve benzerleri üzerindeki haklar ve payların (intifa-kullanım hakkı dahil) temsil edildiği ya da bir projede ya da özel bir yatırım faaliyetinde ortaklık hakkı veren sertifikalardır (Tok, 2009:14).

Sukuk, geleneksel tahvil ve bonolara bir alternatif olarak geliştirilmiş olup temel ilkesi İslami prensiplerle uyum içinde olmasıdır. İslami prensipler ise faizi yasaklamaktadır. İslami prensiplere göre borç alanlar, borç verenlerin iş ortağı olarak kabul edilmektedir. Yatırımın risk ve getirisi borç alan ve borç veren arasında paylaşılmaktadır. İslami tahviller, yapılandırılmış finansal araçlar olup bir ticari işleme dayanmaktadır. Söz konusu ticari işlem ise sukukun türüne göre, vadeli olarak varlık alım ve satımı, bir varlığın kiralanması, ortak girişim kurulması şeklinde olabilir (Yakar vd., 2013:74).

Sukuk, ilgili varlığın değeriyle orantılı oluşturulan sertifikalar aracılığıyla varlığın mülkiyetinin geniş yatırımcı kitlesine transfer edildiği bir süreç olan menkulleştirmeye benzemektedir (Güngören, 2011:96).

Sukuk yapısı ve oluşturulma şekli itibariyle ve dayandığı prensipler açısından kendine has bazı özelliklere sahiptir (Aslan, 2012:56):

- Faiz, prensip gereği yasak olduğundan sukuk getirileri faizli olmak yerine, kira geliri veya kar payı şeklindedir.

- Sukuk likit bir finansal araçtır. Çeşidine göre ikincil piyasalarda da işlem görebilmektedir.

- Sukuk işlemlerinde, İslami finansman prensipleri gereği yüksek belirsizlik içeren işlemlerden uzak durulmaktadır.

- Sukuk, sahibinin hak ve yükümlülüklerini belirten senetler olup nama veya hamiline düzenlenerek ihraç edilebilmektedir.

- Sukuk, İslam hukuku esaslarına göre düzenlenmektedir. İkincil piyasada işlem görmesi de bu kurallar dahilinde söz konusu olmaktadır. 
- Sukuk yatırımcıları kara, sukuk ihracında belirtilen paylaşma oranına göre, zarara ise ortaklık payına göre katılmaktadır.

- Sukuk, dayanak varlık olan mal, hizmet veya menfaat üzerinde müşterek mülkiyet payını temsil eder.

Aşağıda belirtilen sukuk çeşitleri ile sukukun özellikleri daha iyi anlaşılacaktır.

\section{SUKUK ÇEŞITTLERI}

Sukuk genel olarak üç temel kullanım alanına sahiptir. Proje endeksli sukuklarda, yapılması planlanan bir projenin finansmanını sağlaması için sukuk ihraç edilmektedir. Varlık endeksli sukuklarda, firmaların sahip oldukları varlıklardan elde edecekleri kazanç hakkının yatırımcılara satılması ile fon elde edilmektedir. Bilanço endeksli sukuklarda ise, birden fazla projeye birden fon temin etmek için sukuk ihraç edilmektedir (Aslan, 2012: 63-64). Kullanım alanlarına göre bu şekilde sınıflandırılan sukukların AAOIFI tarafından onaylanmış 14 çeşit uygulaması mevcuttur. Uluslararası derecelendirme şirketi Moody's'in yaptığı bir araştırmada; Ortadoğu, Afrika ve Asya Pasifik ülkelerindeki sukuk işlemlerinde Muşaraka (kâr-zarar paylaşımı) sukuku, toplam sukuk ihracının \%40'ını oluşturmaktadır. Ardından icara (kiralama) ve mudaraba (kâr paylaşımı) sukukları gelmiştir ( Altaş, 2008:26). Finansman şekillerine çeşitlilik gösterilen sukuklar içerisinden en yaygın kullanılan sukuklar aşağıda açıklanmıştır.

\subsection{Mudaraba Sukuk}

Mudaraba, her türlü girişime kâr-zarar ortaklığı kapsamında yönetim desteği vererek özsermaye temin edilmesi olup, bu açıdan risk sermayesine benzer bir yapı çizmektedir. Mudaraba sukukta sertifika ihraççısı mudaribtir (girişimci). Fon verenler sermaye sahipleridir ve toplanan fonlar mudaraba sermayesidir. Sertifika sahipleri mudaraba faaliyetindeki varlıkların ve anlaşma başına düşen kâr payının sahibidir (Tok, 2012:18). Ancak elde edilen kâr önceden belirlenen oran üzerinden iki taraf arasında paylaşılırken, zarar sadece sermaye sahibi tarafından karşılanmaktadır (Khan, 2003:129).

Mudaraba (Emek-sermaye ortaklığı) sukuk, bir bankanın girişimciye sağlayacağı finansman desteğine fon bulabilmek amacıyla sertifika çıkarma yoluna gitmesi halinde, çıkarılan sertifikalara verilen isimdir. Buna göre mudaraba banka ile girişimci arasında yapılan bir kar ortaklığı anlaşmasıdır. Sertifikaların satışı sonunda sağlanan fonun girişimciye aktarılması karşılığında da banka girişimcinin yürüttüğü profesyonel faaliyetten kaynaklanan kâra önceden anlaşılmış oranlarda ortaklık hakkı elde etmektedir. Öte yandan, zaman içinde sukuka konu olan varlığın piyasa değerinde bir artış olması halinde sukuk sahibinin herhangi bir hakkı bulunmamaktadır. Ayrıca mudaraba sukuk sahiplerinin şirketin kayıtlı ortakları olmamaları da, onların genel kurulda söz sahibi olmalarını engellemektedir (Büyükakın ve Önyılmaz, 2012:5). Mudaraba sisteminde, taraflardan birinin emek, bilgi ve tecrübesini ortaya 
koyması, diğer tarafın (banka) sermayesi ile ortak olması risk sermayesi yönetimine benzer bir yapılanmayı işaret etmektedir.

Örnek 1: X Şirketi, bir y1l sonra teslim etmek üzere 10.000.000 TL'lık bir devremülk inşaat ihalesini almıştır. Ayrıca projenin zamanında bitirilmemesi halinde, gecikilen her ay için \%5 oranında eksik ödeme yapılması öngörülmüştür. Projenin maliyeti 7.000.000 TL olarak tahmin edilmiş ve bu projenin finansmanında kullanılmak üzere 7.000.000 TL'lık sukuk ihracı yapılmıştır. Buna göre projenin kârı olan 3.000.000 TL, sermaye sahibi olan sukuk sertifikası sahipleri ile inşaat firması ( kaynak kuruluş, mudarip) arasında paylaşılacaktır. Eğer proje zamanında bitirilirse, 3.000.000 TL'lık gelirin yarısı sukuk yatırımcıları, diğer yarısı inşaat şirketi arasında bölüşülecektir. Ancak iki aylık bir gecikme söz konusu olursa, toplam 1.000.000 TL eksik tahsilat yapılacak ve toplamda 2.000.000 TL gelir tahsil edilerek paylaşılacaktır. Projenin 8 ay gecikmeli olarak teslim edilmesi halinde ise 4.000.000 liralık eksik tahsilâtla toplam 6.000.000 TL tahsil edilecektir. Dolayısıyla projeden 1.000.000 TL zarar edilmiş olacak ve bu zarar sermaye sahibi olan sukuk yatırımcısı tarafından karşılanacaktır.

\subsection{Muşaraka Sukuk}

Mudaraba sisteminde emek-sermaye ortaklığı söz konusuyken, bu sistemde hem emek hem de sermaye ortaklığı söz konusu olmaktadır. Farklı veya aynı oranda sermaye katılımıyla ortak olunabilmektedir. Her bir ortak belirtilmiş olan sınırlar dahilinde sermayeyi kullanma yetkisine sahip olmaktadır. Ticari faaliyetler tek bir alanda sınırlandırılabileceği gibi anlaşma sağlanırsa birçok alanda uygulanabilecek şekilde de belirlenebilmektedir. Zararın paylaşımı sermaye katılımı oranında pay edilmekte olmasına rağmen kârın paylaşımı anlaşmaya göre farklı olabilmektedir (Uçar, 1993:129). Müşaraka Sukuku, ortaklık sözleşmesine dayalı mevcut bir işin finansmanını geliştirmek veya yeni bir projeyi tesis etmek için kullanılır. Sertifikayı elinde bulunduranlar hisseleri oranında projenin veya faaliyetin sahibi olurlar. Her ne kadar bu sertifikalara sahip olunmasıyla likit olmayan varlıklar üzerinde mülkiyet doğsa da, Müşaraka tahvilleri ikincil piyasada alınıp satılabildiğinden, likit özelliğe sahiptir. Bir başka deyişle Müşaraka sertifikaları ciro edilebilir enstrüman olarak işlem görür ve ikincil piyasalarda alınıp satılabilir (Tok:2009,19). Kâr-zarar ortaklığı esasına dayanan Müşaraka, belli bir işin finansmanını gerçekleştirmek üzere çıkardığı tahvillerle başka bir şirketi ortaklığa davet etmektedir. Söz konusu işin finansmanında fonları ile katkıda bulunan ortaklar da ortaklığın varlıkları üzerinde söz sahibi olmakta ve kârdan pay alma hakkına sahip olmaktadır. Muşaraka sukuku ile ilgili süreç aşağıdaki gibi özetlenebilir (Güngören, 2011:105):

Sabit bir dönem ve anlaşılan kâr paylaşımı için SPV (Özel Amaçlı Şirket) ve şirket muşaraka anlaşması yaparlar. Şirket periyodik olarak SPV'nin muşaraka hisselerini satın almayı garanti eder. 
- $\quad$ Şirket (Muşaraka katılımcısı olarak) muşarakaya konu olan toprağa veya diğer fiziksel aktiflere katkıda bulunur.

SPV (Muşaraka katılımcısı olarak) nakit katkıda bulunur.

- $\quad$ Muşaraka, eklenen ilave nakitlerle toprağı veya fiziksel değerleri geliştirmesi için ve geliştirilen değerleri Muşaraka namına satıp/kiralaması için bir şirketi yetkili acente atar.

- $\quad$ Yetkili acente (şirket) sabit acente ücretine ilave olarak teşvik edici değişken ücret elde edecektir.

Faaliyet sonucu elde edilen kârlar sukuk hissedarlarına dağıtılır.

- $\quad$ Şirket, yarıyıl esasına göre SPV'nin muşaraka hisselerini önceden anlaşılan fiyat üzerinden satın almayı cayılamaz şekilde garanti eder ve sabitlenmiş dönem sonunda SPV'nın muşaraka da hiçbir hissesi kalmaz.

Örnek 2: . Örnek 1'de belirtildiği üzere X Şirketi, 10.000.000 TL'lık bir devremülk inşaat ihalesini bir yıl sonra teslim etmek üzere almıştır. Ayrıca projenin zamanında bitirilmemesi halinde, gecikilen her ay için $\% 5$ oranında eksik ödeme yapılması öngörülmüştür. Projenin maliyeti 7.000.000 TL olarak tahmin edilmiştir. Örnek 1'den farklı olarak; X Şirketi, projenin maliyetinin 3.500.000 liralık kısmını özkaynakları ile, kalan kısmı için 3.500.000 liralık muşaraka sukuk ihracı gerçekleştirmiştir. Buna göre sukuk yatırımcıları projeye finansman desteğinde bulunurken aynı zamanda \%50 oranında projenin de sahibi olmaktadır. Dolayısıyla Projenin sonunda elde edilen gelir inşaat şirketi ve sukuk sahipleri arasında mudaraba sukukta olduğu gibi paylaşılacaktır. Ancak projenin sonunda zarar olması durumunda zarar, mudaraba sukuktan farklı olarak, sukuk yatırımcısı ile X şirketi arasında sermayeleri oranında paylaşılacaktır.

\subsection{Murabaha Sukuk:}

Murabaha, bir malın maliyetine önceden üzerinde anlaşılmış miktar kadar kâr ilave edilerek yapılan satış işlemi olarak tanımlanmaktadır (Khan, 2003:26).

Bu sukuk türünde sertifika ihraç eden taraf emtia murabahası satıcısı, murabaha alan emtianın alıcısı ve fon da emtianın satın alma maliyetidir. Sertifika sahipleri murabaha emtiasına sahip olurlar ve emtianın tekrar satışında nihai satış fiyatı hakkına sahiptirler. Murabaha temelli sukukun hukuki olarak geçerli olması için sadece birincil piyasada işlem görmesi gerekir. Sukukun ciro edilmesi veya ikincil piyasada işlem görmesine İslam hukuku tarafından izin verilmemiştir. Çünkü sertifikalar, emtia alıcısının sertifika sahiplerine borcunu temsil etmektedir ve borcun vadeli olarak alınıp satılması faizle sonuçlanacağından izin verilmemiştir (Tok:2009:21). Murabaha sukuku ile toplanan fonlarla malların peşin alınıp, belli kâr oranı eklendikten sonra vadeli olarak satılması ve yatırımcının son satış fiyatı üzerinden alacak hakkına sahip olması esasına dayanmaktadır.

Murabaha sukuku ile ilgili süreç aşağıdaki gibi özetlenebilir (Güngören, 2011:108109): 
- $\quad$ SPV ve borçlu arasında ana sözleşme imzalanır.

- $\quad$ SPV yatırımcılara sukuk ihraç eder ve sukuk getirisi alır.

- $\quad$ SPV emtia satıcısından cari piyasadan (spotta) emtia satın alır.

- SPV emtiayı kâr marjını ekleyerek cari piyasa fiyatından anlaşılan zaman diliminde taksitli ödenmek üzere borçluya satar.

- $\quad$ Borçlu emtiayı cari piyasada emtia alıcısına satar.

- Yatırımcılar nihai satış bedeli ve getiri elde ederler.

Örnek 3: X şirketi 1.000.000 TL değerindeki bir makineyi almak için özel amaçlı şirket (SPV) ile bir sözleşme yapar. SPV, söz konusu makinenin alımı için her biri $100 \mathrm{TL}$ değerinde 10.000 adet sukuk ihraç eder ve ihraçtan elde edilen fonlarla makineyi satın alır. Alığı makinenin bedeline 250.000 TL kâr payı ilave ederek X şirketine 20 ay vade ile satar. X Şirketi 20 ay boyunca her ay (1.250.000/20) 62.500 TL taksiti SPV'ye öder. SPV de taksitlerle sukuk yatırımcılarına anapara ve kâr paylarını geri öder. Böylece X Şirketi makinenin finansmanını sağlarken, sukuk yatırımcıları da bu süre içerisinde 250.000 liralık gelir elde etmiş olurlar.

\subsection{Salam Sukuk}

Salam (selem) sukuk, türev ürünlerinden forward uygulamasına benzemektedir. Salam sukuk sözleşmesine göre, bir satıcı belirli bir malı ileride belirlenen bir tarihte teslim edeceğini taahhüt etmekte ve bedelini peşin olarak almaktadır. Ancak forward, gerçekte bir belirsizlik içerdiği ve belirsizlikte faiz doğurduğu için İslam dininde yasaklanmıştır (Türker, 2010:9). Bu nedenle sukuğa konu olan malın bedelinin tamamının önceden ödenmesi, malın teslim tarihinin sabit olması ve malın vadesi gelmeden ikinci bir satışının yapılamaması gibi koşullar getirilerek belirsizliğin ortadan kaldırılması yoluna gidilmiştir (Büyükakın ve Önyılmaz, 2012:3). Selem (future sale) kapsamındaki işlemlerde malın fiyatı spot piyasada ödenir, ancak teslim edilmesi belli bir süre sonra gerçekleşir. Yapılan anlaşmalarla ticaretin konusu, fiyatı ve teslim tarihi tam olarak belirlenir. Mal zamanında teslim edilmezse alıcı ödemesini geri alır ya da mal teslim edilinceye kadar beklemeyi tercih edebilir (Tok:2009:12).

Salam (İleriye dönük satın alma) sukuk, işleme konu olan salam bazlı malın alımı için fon toplamak amacıyla çıkarılmış sertifikalardır (Türker, 2010:9). Selem sözleşmesi, genellikle tahıl, petrol, demir ve benzeri ölçülebilir ve standartlaştırılabilir emtia üzerine yapılmaktadırlar. Bu sözleşmelerin finansmanı için çıkarılan sukuklar ikinci el piyasada nominal değer üzerinden işlem görebilmekte olup, emtianın teslim tarihindeki fiyatına yönelik beklentiler doğrultusunda alınıp satılabilmektedir (Küçükçolak, 2008:34).

Selem belirli bir malın veya hizmetin bedelinin tamamının peşin olarak ödenip ileri bir vadede satın alınmasıdır. Banka peşin ödeme yaparak gelecekte üretilecek olan malı satın alır. Fakat bu malı satmak için vadesini beklemek zorundadır. Hâlihazırda var olmayan ve gelecekte üretilecek bir malın satılması işlemidir (SERPAM, 2013:5). Örneğin, Bahreyn hükümetinin 2000 yılında çıkardığı sukuk ihracı salam sözleşmesi şeklinde olmuştur. Salam 
sukukunun dayanak varlığı alüminyum olarak belirlenmiştir. Sözleşmede alıcıya, peşin ödeme yapması karşılığında, belirlenmiş ileri bir tarihte alüminyum satılacağı taahhüt edilmiştir. $\mathrm{Bu}$ işlemde Bahreyn İslam Bankası (BIB) salam sözleşmesine katılmak isteyen diğer bankaları temsil etmek üzere görevlendirilmiştir. Aynı zamanda malın dağıtım kanalları ile pazarlaması için Bahreyn Hükümeti acente olarak görevlendirilmiştir. Bahreyn Hükümeti, BIB'ın salam sahiplerine diğer geleneksel kısa vadeli para piyasası enstrümanlarının getirisine eşit kazanç sağlayacak bir fiyattan alüminyum satmasına olanak sağlamıştır (Altaş, 2008:22).

\section{5. İcara Sukuk}

İcara (Ijarah)(Leasing, Kira finansmanı)sukuk, bir kira anlaşmasıdır ve icara anlaşması ile konu edilen gayrimenkulün intifa (kullanım) hakkı mal sahibinden kontrat sahibine geçmektedir. Buradaki icara kelimesi ise, mal sahibine ödenen kira anlamı taşımaktadır. Büyük ölçüde finansal kiralama olarak bildiğimiz leasinge benzeyen icara sukuk, kiraciya kiralama periyodu sonunda kiralanan varlığı alma hakkı da tanımaktadır. Ancak icara sukuk sahipleri, varlığın mülkiyet hakkının yanında varlıktan kira alma hakkına da sahip olabilmektedirler. İcara sukuk ciro edilebilmekte, ikincil piyasalarda işlem görebilmekte ve hatta kiralanan varlığın kaza veya afet sonucunda kullanılamaz hale gelmesi halinde kiracı icara kontratını iptal edebilmektedir. Fakat günümüzdeki uygulamalarda kiralanan varlık bu gibi durumlara karşı sigortalanmaktadır. İcara sukuka konu olan varlık için kira getiri oranı ise anlaşmaya bağlı olarak sabit veya değişken olabilmektedir (Büyükakın ve Önyılmaz, 2012:4). Türkiye' de varlık kiralama şirketleri tarafından çıkarılan kira sertifikaları (sukuku) icara sukukun bir uygulaması olup, sistemin işleyişi ilgili bilgiler bir sonraki bölümde açıklanmıştır.

\section{TÜRKIYYE'DE SUKUK UYGULAMASI}

\subsection{Kira Sertifikaları (Sukuku) İle İlgili Yasal Düzenlemeler ve İşleyişi}

Türkiye'de sukuk uygulaması, Varlık Kiralama Şirketleri (VKŞ) tarafından çıkarılan kira sertifikaları şeklinde ortaya çıkmıştır. Çeşitli sukuk uygulamaları arasında sadece İcara Sukuk olarak ifade edilen kira sukuku ile ilgili mevzuat hazırlanmıştır. Sermaye Piyasası Kurulu tarafından yeni sermaye piyasası araçlarının Türkiye finansal piyasalarında işlem görmesine yönelik çalışmalar kapsamında hazırlanan Seri: III, No: 43 sayılı "Kira Sertifikalarına ve Varlık Kiralama Şirketlerine İlişkin Esaslar Hakkında Tebliğ" 01/04/2010 tarih ve 27539 sayılı Resmi Gazete'de yayımlanarak yürürlüğe girmiştir. Bu tebliğ ile, özel sektör şirketlerinin kira sertifikası ihracı imkanı ortaya çıkmış ve bu enstrüman ile sermaye piyasalarından fon temin etmelerine imkân tanınmıştır.

Tebliğde yer alan bazı kavramların tanımı tebliğin 3.maddesinde aşağıdaki gibi yapılmıştır: 
Kaynak kuruluş: Sahip olduğu veya kiraladığı varlıkları, kiralamak üzere varlık kiralama şirketine devreden anonim şirketidir.

Kira sertifikası: Varlık kiralama şirketinin satın almak veya kiralamak suretiyle devraldığı varlıkların finansmanını sağlamak amacıyla düzenlediği ve sahiplerinin bu varlıklardan elde edilen gelirlerden payları oranında hak sahibi olmalarını sağlayan menkul kıymet, kira sukukudur.

Kurucu: Aracı kurumlar, bankalar ve kaynak kuruluşlarıdır.

Varlık: Varlık kiralama şirketinin satın alacağı veya kiralayacağı her türlü menkul veya gayrimenkul malları ve maddi olmayan varlıklardır.

Varlık kiralama şirketi (VKŞ): Aracı kurumlar, bankalar ve kaynak kuruluşlar tarafından münhasıran kira sertifikası ihraç etmek üzere kurulmuş olan anonim şirkettir.

Tebliğ varlık kiralama şirketleri ve kira sertifikaları ile ilgili düzenlemelerle ilgili olsa da, esas olarak söz konusu olan bir kira sukukudur. Zaten kira sertifikası ile ilgili tanımın sonunda bu sertifikaların aynı zamanda kira sukuku olduğu ifade edilmiştir.

İlgili tebliğ ile yayınlanan düzenlemeler ve Kira Sertifikasına ilişkin genel esaslara aşağıda yer verilmektedir(turkiyefinans.com.tr, 2013):

Katılım Bankacılığı prensipleri ile uyumlu "faizsiz tahvil" olarak da tanımlanan ve global bir yatırım aracı haline gelen Sukuk'a benzer bir enstrüman olarak Kira Sertifikası oluşturulmuştur.

Tebliğ ile yatırımcı hakları koruma altına alınmış, VKŞ tarafından yatırımcılar hesabına devralınmış olan varlıkların veya bu varlıklardan elde edilen gelirlerin amacı dışında kullanılmasının önlenmesini teminen, VKŞ esas sözleşmesinin Sermaye Piyasası Kurulu onayı zorunlu tutulmuştur.

Tahvil ile benzer işleyiş yapısına sahip olan Kira Sertifikasının, satış sonrasında nakdi kaynak girişine imkân verecek dayanak bir varlığa bağlı olarak ihraç edilmesi, yani daha korumalı bir teminat yapısı içeriyor olması nedeniyle yatırımcılar açısından güvenli bir ürün olarak ön plana çıkacaktır.

Sistem temel olarak, kaynak kuruluşun VKŞ'ye devrettiği varlıkları daha sonra geri kiralaması suretiyle fon temin etmesi ve bu kira gelirinin pay sahiplerine hakları oranında dağıtılması üzerine kurgulanmıştır. VKŞ, ilk etapta devraldığı bu varlıkların finansmanını ihraç edeceği kira sertifikası ile karşılamakta, söz konusu sertifikaların dönemsel ödemelerini ise kaynak kuruluştan gelen dönemsel kira gelirleri ile gerçekleştirmektedir. Vade sonunda ise kaynak kuruluşa geri devredilen söz konusu varlıklardan elde edilen gelir, kira sertifikası sahiplerine payları oranında dağıtılarak ihraç edilmiş olan kira sertifikası itfa edilmektedir.

Tebliğin 5. maddesinde VKŞ’nin faaliyet konusuna esas sözleşmesinde yer alacak faaliyetler şu şekilde belirlenmiştir;

a) Kira sertifikası ihraç etmek, 
b) Kendi nam ve kira sertifikası sahipleri hesabına her türlü varlığı devralmak, kiralamak, varlıklardan elde edilen gelirleri payları oranında kira sertifikası sahiplerine ödemek,

c) Kira sözleşmesinin sonunda, başlangıçta anlaşılan koşullarda kiraya konu varlığı kaynak kuruluşa devretmek.

Şekil 1: Kira Sukukunun İşleyişi

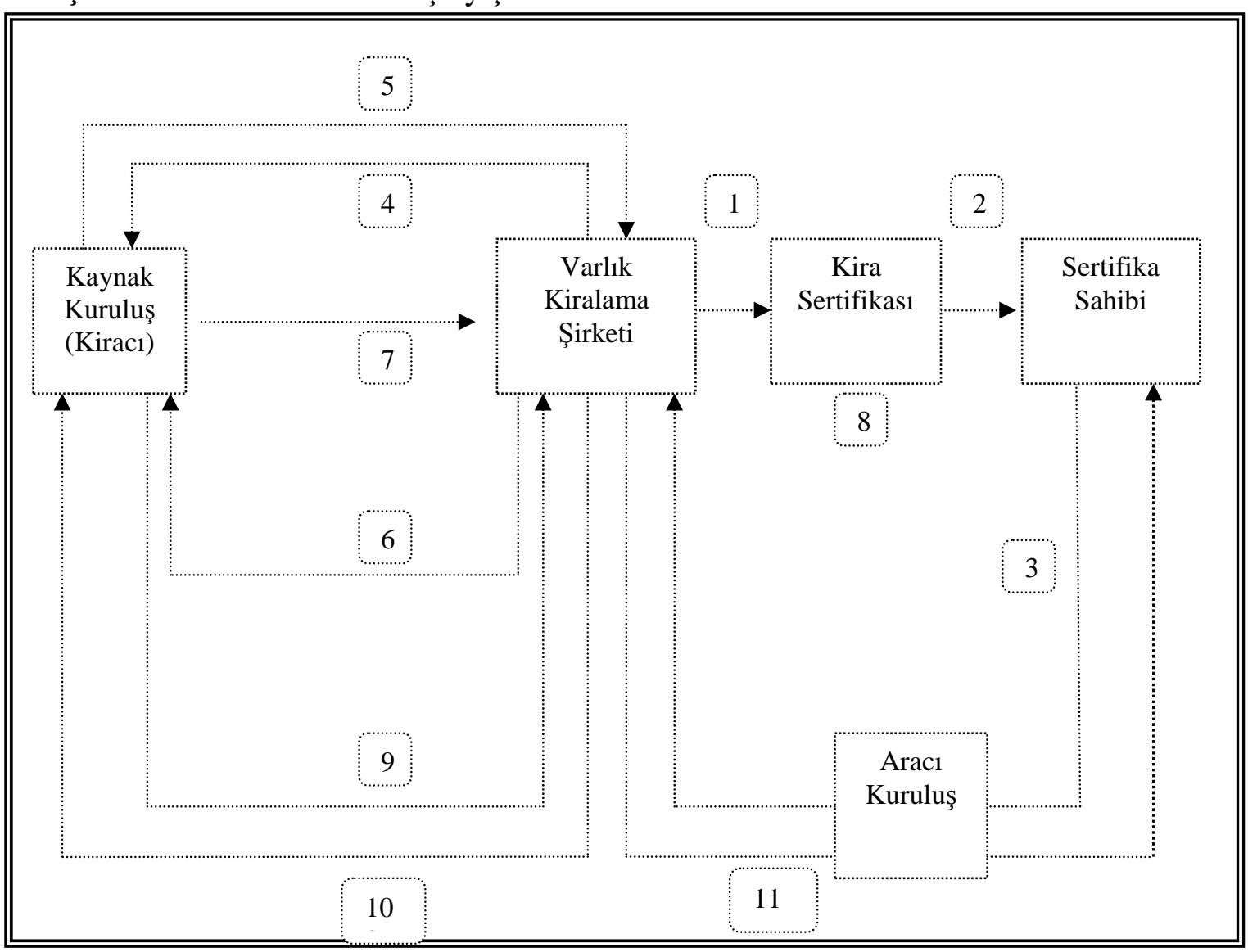

Kaynak: turkiyefinans.com (2013)'dan uyarlanmıştır.

Kira sertifikalarının ihraç edilebilmesi için öncelikle sadece bu amaçla bir varlık kiralama şirketinin kurulması gerekir. Bu şirketin kurulmasıyla yukarıdaki şemada belirtilen sürecin işleyişi başlar. Sürecin işleyişini gösteren şemanın işlem basamakları aşağıda belirtilmiştir.

1.adım: VKŞ, varlığın toplam bedeline eşdeğerde kira sertifikalarını ihraç eder.

2.adım: Yatırımcılar kira sertifikalarını satın alırlar.

3.adım: Yatırımcılar kira sertifikalarının toplam bedelini VKŞ'ine öderler.

4.adım: VKŞ, tahsil ettiği kira sertifikaları bedelini kiralamaya konu olan varlığı satın almak üzere kaynak kuruluşa aktarır. 
5.adım: Kaynak kuruluş, kiralamaya konu olacak varlığın mülkiyetini vadenin sonunda geri satın almak üzere VKŞ'ine devreder.

6.adım: VKŞ, mülkiyetini devraldığı varlıkla ilgili bir kira sözleşmesi yaparak kira sertifikalarında belirtilen vadenin sonuna kadar kaynak kuruluşa kiralar.

7.adım: Kaynak kuruluş söz konusu varlığın kira bedelini düzenli olarak belirli periyotlarla (örneğin aylık olarak) VKŞ'ne öder.

8.adım: VKŞ, kaynak kuruluştan aldığı kira bedellerini yatırımcılara kira sertifikalarının periyodik ödemelerinde kullanılır.

9.adım: Kira sertifikalarında belirtilen vadenin sonunda kaynak kuruluş, daha önce mülkiyetini VKŞ’ne belli bir bedel karşılığında devrettiği varlığın mülkiyetini tekrar almak üzere aynı tutarı VKŞ'ne öder.

10.adım: VKŞ, vade sonunda kiralamaya konu olan varlığın mülkiyetini kaynak kuruluşa devreder.

11.adım: VKȘ, 1.ve 2. adım gereği yatırımcılardan tahsil ettiği kira sertifikaları ana paralarını geri öder.

Kira sertifikaları aynı zamanda kira sukuku olarak da bilinmektedir ve Türkiye'de sukuk uygulamalarına ilişkin ilk çalışmadır. 17 Ağustos 2010' da Kuveyt Türk Katılım Bankası tarafından gerçekleştirilen ilk ihraç 100 milyon dolar değerindedir ve senetler \%.5.25 sabit getiri oranlı olarak Ağustos 2013 tarihine kadar vadeli olacak şekilde işleme tabi tutulmuştur. Nüfusunun büyük bir çoğunluğu Müslüman olan Türkiye' de İslami kurallara uygun bir tahvil olan sukuk ihracının bu ilk uygulaması büyük ilgi görmüş ve ülkenin alternatif İslami finansal yapılara açık ve hazır olduğunun bir göstergesi sayılmıştır (Büyükakın ve Önyılmaz, 2012:10) Hazine Müsteşarlığı tarafından 18 Eylül 2012 tarihinde Citigroup, HSBC ve Liquty house üçlüsüne yetki verilerek 1,5 milyar dolar tutarında sukuk satışa çıkarılmıştır. İlk gerçekleştirilen ihalenin sonucunda 5 kat talep gelmiştir. Sukukun \%58'i Ortadoğu, \%13'ü Avrupa, \%12'si Asya, \%9'u Türkiye ve \%8'i de ABD'deki yatırımcılara satılmıştır (Halıcı ve Halıcı, 2013:238).

\subsection{Türkiye'de Kira Sertifikalarının (Sukukunun) Vergilendirilmesi}

Kira sertifikalarının vergilendirilmesi ile ilgili yasal düzenleme 13.02.2011 tarihli Resmi Gazete de yayımlanan 6111 sayılı kanun ile düzenlenmiștir. Söz konusu kanun ile Kurumlar Vergisi Kanunu, Gelir Vergisi Kanunu, Harçlar Kanunu ve Damga Vergisi Kanununda değişiklikler yapılarak kira sertifikalarının vergilendirilmesinde yasal dayanaklar oluşturulmuştur. ${ }^{1}$

5520 sayılı Kurumlar Vergisi Kanununun İstisna başlıklı 5'inci maddesine "taşınmazların; kaynak kuruluşlarca, kira sertifikası ihracı amacıyla varlık kiralama

\footnotetext{
${ }^{1}$ Vergi Kanunları ile ilgili kanun maddelerine atıfta bulunulurken okuyucuların dikkatini çekmek için bazı alanlar italik yazılmış, vergi kanunlarının adları da koyu olarak yazılmıştır.
} 
şirketlerine satışı ile 21/11/2012 tarihli ve 6361 sayılı Finansal Kiralama, Faktoring ve Finansman Şirketleri Kanunu kapsamında geri kiralama amacıyla ve sözleşme sonunda geri alınması şartıyla, finansal kiralama şirketlerine satışı ve varlık kiralama ile finansal kiralama

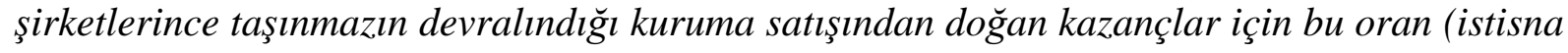
oranı) \%100 olarak uygulanır ve bu taşınmazlar için en az iki tam yıl süreyle aktifte bulunma şartı aranmaz. Ancak söz konusu taşınmazların; kaynak kuruluş, kiracı veya sözleşmeden kaynaklanan yükümlülüklerin yerine getirilememesi hâli hariç olmak üzere, varlık kiralama veya finansal kiralama şirketi tarafından üçüncü kişi ve kurumlara satılması durumunda, bu taşınmazların kaynak kuruluşta veya kiracıdaki varlık kiralama veya finansal kiralama şirketine devirden önceki kayıtlı değeri ile anılan kurumlarda ayrllan toplam amortisman tutarı dikkate alınarak satışı gerçekleştiren kurum nezdinde vergilendirme yapılır” hükmü eklenerek kurumların en az iki tam yıl süreyle aktiflerinde yer alan taşınmazlar ve iştirak hisseleri ile aynı süreyle sahip oldukları kurucu senetleri, intifa senetleri ve rüçhan haklarının satışından doğan kazançlar için uygulanan \%75'lik istisna oranı kira sertifikaları için \%100 uygulanması ve iki yıllık aktifte bulunma şartının aranmaması ifadelerine yer verilmiştir.

Gelir Vergisi Kanununun da yapılan değişiklikle GVK 75/5. maddesi varlık kiralama şirketleri tarafından ihraç edilen kira sertifikalarından sağlanan gelirleri de kapsayacak şekilde genişletilmiş ve varlık kiralama şirketleri tarafından ihraç edilen kira sertifikalarından elde

edilen gelirlerin menkul sermaye iradı olduğu hüküm altına alınmıştır.

488 sayılı Damga Vergisi kanununa 6111 sayılı Kanun ile eklenen bir fikra ile “ Menkul, gayrimenkul ve maddi olmayan varlıkların varlık kiralama şirketlerine devri, bunların varlık kiralama şirketince devralınan kuruma devri, bu devirleler bağlı olarak yapılan ipotek işlemleri ile bunların varlık kiralama şirketlerince kiralanması nedeniyle düzenlenen kağıtlar ve kira sertifikaları" damga vergisinden istisna tutulmuştur.

492 sayılı Harçlar Kanunun 123'üncü maddesinde "Menkul, gayrimenkul ve maddi olmayan varlıkların, varlık kiralama şirketine devri ile bunların varlık kiralama şirketine devri ile bunların varlık kiralama şirketlerince devralınan kuruma devri ve bu devirlere bağlı olarak yapılan ipotek işlemleri bu Kanunda yazılı harçlardan müstesna" olduğunu ifade edilmiştir.

3065 sayılı Katma değer Vergisi Kanununun 17/4'nü maddesine eklenen bir bent ile menkul, gayrimenkul ve maddi olmayan varlıkların varlık kiralama şirketlerine devri ile bu varlıkların varlık kiralama şirketlerince kiralanması ve devralınan kuruma devri KDV'den istisna tutulmuştur.

29 Haziran 2011 tarihli Resmi Gazete'de yayımlanan 2011/1854 sayılı Bakanlar Kururu Kararı ile varlık kiralama şirketleri tarafından ihraç edilen kira sertifikalarından elde edilen gelirler ve varantlardan sağlanan bazı kazançlara uygulanacak stopaj oranları belirlenmiştir. Bakanlar Kurulu Kararına göre daha önce tahviller için uygulanan stopaj oranları kira sertifikaları için de benimsenmiştir. Buna göre; 
- Varlı kiralama şirketleri tarafından Türkiye'de ihraç edilen kira sertifikalarından să̆lanan gelirler üzerinden \% 10 oranında stopaj yapılacaktır.

- $\quad$ Tam mükellef varlık kiralama şirketleri tarafindan yurt dışında ihraç edilen kira sertifikalarının;

Vadesi 1 yıla kadar olanlara sağlanan gelirlerden \%10,

Vadesi 1 yıl ile 3 yıl arası olanlara sağlanan gelirlerden \% 7 ,

Vadesi 3 yıl ile 5 yıl arası olanlara sağlanan gelirlerden \%3,

Vadesi 5 yll ve daha uzun olanlara sağlanan gelirlerden \%0, oranlarda stopaj yapılacaktır.

$\mathrm{Bu}$ karar ile kira sertifikaları ile gerçekleştirilen bazı işlemlerdeki Banka ve Sigorta Muameleleri Vergisi (BSMV) oranlarına da yer verilmektedir. Buna göre,

- Yurt içinde Türk Lirası cinsinden ihraç edilen tahviller ve varlık kiralama şirketleri tarafından ihraç edilen kira sertifikalarının geri alım ve satım taahhüdü ile iktisap veya elden çıkarılması karşılığında lehe alınan paralar üzerinden \%1,

- Yurt içinde Türk Lirası cinsinden ihraç edilen tahviller ve varlık kiralama şirketleri tarafından ihraç edilen kira sertifikalarının vadesi beklenmeksizin satışı nedeniyle lehe alınan paralar üzerinden \%1 oranında BSMV alınacă̆ı hükme bă̆lanmıştır.

Kira sukuku ile ilgili yapılan vergi düzenlemelerinin genel olarak tahvil için yapılan düzenlemelere paralel olduğu söylenebilir. Dolayısıyla geleneksel tahvil ile karşılaştırıldığında vergi açısından önemli bir avantajı görünmemektedir. Gerek global sukuk pazarından pay almak gerekse inançları gereği geleneksel finansal araçlardan uzak duran tasarruf sahiplerinin tasarruflarını ekonomiye kazandırmak için sukuk çeşitlerinin artırılması ve vergi açısından daha avantajlı hale getirilmesi yararlı olacaktır.

\section{SONUÇ}

Son yıllarda dünya genelinde önemli bir finansal araç haline gelen sukuk, işlem hacmindeki yükseliş trendiyle önemini gittikçe artırmaktadır. Sukuk esas itibariyle çeşitli varlıklara sahip olduğu halde likidite ihtiyacı olan iktisadi birimlerin ve yeni bir iş yapma isteğinde olup gerekli fona sahip olmayan kişilerin fon temin etmelerinde kullandıkları bir araç olarak görülmektedir. Global sukuk piyasasında başta Malezya olmak üzere nüfusunun çoğunluğunu Müslümanların oluşturduğu ülkeler etkin rol oynamaktadır. Körfez ülkelerinin trilyonlarca dolarlık sermayelerini ülkelerine çekmek isteyen A.B.D, Japonya ve batı Avrupa ülkeleri de sukuk piyasası ile ilgili düzenlemeler yapmaktadırlar. Türkiye de 2010 yılından itibaren yaptığı yasal düzenlemelerle sukuk piyasasına girmiş bulunmaktadır. Türkiye'deki uygulama, sukuk çeşitlerinden icara sukukun uygulaması olup, varlık kiralama şirketleri tarafından kira sertifikalarının (sukukunun) ihraç edilmesi yoluyla fon elde etme esasına dayanmaktadır. Global sukuk pazarındaki çeşitlilik dikkate alındığında bu uygulamanın oldukça dar kapsamlı olduğu söylenebilir. Gerek yurtdışında gerekse yurtiçinde özellikle dini hassasiyetlerinden dolayı geleneksel bankacılık sisteminin dışında kalan ve yastık altı olarak 
ifade edilen kaynakların ekonomiye kazandırılması için mevzuatta diğer sukuk çeşitleri ile ilgili düzenlemelerin yapılmasında fayda olacaktır. Ayrıca sukukun vergilendirilmesi ile ilgili yapılan düzenlemeler incelendiğinde genellikle geleneksel tahvil için öngörülen düzenlemelere paralel bir yapı olduğu söylenebilir. Türkiye'nin global sukuk pazarından daha fazla pay alabilmesinde vergi oranlarının daha avantajlı hale getirilmesi önemli bir rol oynayacaktır.

\section{KAYNAKLAR}

Altaş, Gökben (2008), “İslami Finans Sistemi”, Sermaye Piyasasında Gündem Raporu, Sayı 69, Mayıs 2008, ss. 18-29.

Aslan, Hakan (2012), "Alternatif Bir Yatırım ve Finansman Aracı Olarak Sukuk: Yapısı, İşleyişi Ve Türkiye Piyasası İçin Öneriler”, Yüksek Lisans Tezi, Marmara Üniversitesi Sosyal Bilimler Enstitüsü İşletme Anabilim Dalı, İstanbul.

Büyükakın, Figen- Önyılmaz Onur (2012), "Faizsiz Finansman Bonosu Sukuk ve Türkiye Uygulamaları", Finansal Araştırmalar ve Çalışmalar Dergisi, Marmara Üniversitesi Bankacılık ve Sigortacılık Yüksekokulu, Sayı 7, ss.1-16.

Derigs, Ulrich- Marzban, Shehab (2008). "Review and Analysis of Current ShariahCompliant Equity Screening Practices" International Journal of Islamic and Middle Eastern Finance and Management, Vol. 1, No. 4, pp.285- 303.

Durmuş, Abdullah (2010), "Modern Bir Finansal Araç Olarak Sukuk ve Fıkhi Açıdan Tahlili”, İslam Hukuku Araştırmaları Dergisi. Sayı16, ss.141-156.

Ece, Nalan (2011), “Dünya'da Ve Türk Bankacılık Sektöründe İslam Bankalarının Gelişimi”, Akademik Bakış Dergisi, Uluslararası Hakemli Sosyal Bilimler E-Dergisi, Sayı 25, ss.1-17

ERNST\&YOUNG (2013), Turkey News, http://www.ey.com/Publication/vwLUAssets /TurkEYnews /\$FILE/ Approved\%20EYmagazin mayis_11.pdf, (10.09.2013)

Güngören, Muaz (2011), Katılım Bankalarında Menkul Kıymet İhracının (Seküritizasyon) Yapısal Farklılık Gösteren Finansal Piyasalarda Uyum Modellemesi: Sukuk Örneği. Yayımlanmamış Doktora Tezi, T.C. Kadir Has Üniversitesi Sosyal Bilimler Enstitüsü Finans Bankacılık Anabilim Dalı, İstanbul-2011. 
Halıcı, Ümit Arif - Halıcı Ayşe (2013), "Finansman Temininde Yeni Bir Argüman: Sukuk (Varlığa Dayalı Kira Sertifikası), Lebib Yalkın Dergisi, Sayı 117, ss.238-245.

IIFM (International Islamic Finance Market), Sukuk Report (3rd Edition): A Comprehensive Study of the International Sukuk Market, http://www.iifm.net /documents/iifm-sukukreport, $(10.10 .2013)$

Khan, Muhammad Akram, Islamic Economics and Finance: Glossary. 2.Edition. London: Routledge, 2003.

Küçükçolak, Necla (2008), "Faizsiz Finansman Sertifikası Sukuk’un Türk Sermaye Piyasası Açısından Değerlendirilmesi”, Finans Politik ve Ekonomik Yorumlar Dergisi, Sayı 520, ss. $23-37$

Nathif J. Adam and Abdulkader Thomas, Islamic Bonds, 1st Edition, London: Euromoney Books, 2004.

Parlakkaya, Raif - Çürük, Suna Akten (2011), "Finansal rasyoların katılım bankaları ve geleneksel bankalar arasında bir tasnif aracı olarak kullanımı: Türkiye örneğì", Ege Akademik Bakış, Cilt 11, Sayı 3, ss.397-405.

SERPAM (2013), "İslami Finans”, Araştırma Notları, http://serpam.istanbul.edu.tr/wpcontent/uploads/2012/09/Islami_Finans.pdf, (01.09.2013)

Tok, Ahmet (2009), İslami Finans Çerçevesinde Sukuk (İslami Tahvil) Uygulamaları, Katılım Bankaları ve Türkiye Açısından Değerlendirme, 2009, Sermaye Piyayası Kurulu Yeterlik Etüdü.

Türker, Hülya (2010), İslami Finans Sisteminde Finansal Aracılık (Yeterlilik Etüdü), Sermaye Piyasası Kurulu Aracılık Faaliyetleri Dairesi, Ankara.

Vatansever, Nursen (2000), "Varlığa Dayalı Menkul Kıymet Uygulaması Muğla Üniversitesi”, Muğla Üniversitesi SBE Dergisi Güz 2000 Cilt 1, Sayı 1, ss.259-274.

Uçar, Mustafa (1993), Türkiye'de - Dünyada Faizsiz Bankacılık ve Hesap Sistemleri. 1.Basım. İstanbul: Faisal Eğitim ve Yardımlaşma Vakfı Yayınları, 1993.

www.turkiyefinans.com.tr/tr/bireysel_bankacilik/menkul_kiymetler/kira-sertifikasi.aspx 
Yakar Soner, Kandır Serkan Yılmaz, Önal Yıldırım Beyazıt (2013), "Yeni Bir Finansman Aracı Olarak Sukuk-Kira Sertifikası ve Vergisel Boyutunun İncelenmesi” Bankacılar Dergisi, Say1 84, ss.72-94. 